\title{
Protective effects of propofol against hydrogen peroxide- induced oxidative stress in human kidney proximal tubular cells
}

Yu Mi Lee, Jin Woo Shin, Eun Ho Lee, Youngjin Moon, Young Joo Seo, Ji Yeon Kim, and Joung Uk Kim

Department of Anesthesiology and Pain Medicine, Asan Medical Center, Seoul, Korea

Background: We investigated the protective effects of propofol in the HK-2 cell line of human kidney proximal tubular cells against hydrogen peroxide $\left(\mathrm{H}_{2} \mathrm{O}_{2}\right)$-induced oxidative stress.

Methods: After pretreatment with different concentrations of propofol $(0 \mu \mathrm{M}, 10 \mu \mathrm{M}, 25 \mu \mathrm{M}$ and $50 \mu \mathrm{M})$ for 30 minutes, $\mathrm{HK}-2$ cells were exposed to $8 \mathrm{mM} \mathrm{H}_{2} \mathrm{O}_{2}$ for 4 hours. Cell death was assessed by measuring the percentage of lactate dehydrogenase (LDH) release and by counting viable cells. The nature of cell death was assessed by doublestaining cells with fluorescein isothiocyanate-labeled Annexin V and propidium iodide, and then analyzing the cells using flow cytometry.

Results: After exposure to $8 \mathrm{mM} \mathrm{H}_{2} \mathrm{O}_{2}$ for 4 hours, the percentage of $\mathrm{LDH}$ release was $45.1 \pm 4.2 \%$ and the number of viable HK-2 cells was $5.2 \pm 6.0 \%$. Pretreatment with propofol suppressed $\mathrm{H}_{2} \mathrm{O}_{2}$-induced $\mathrm{LDH}$ release in a concentration-dependent manner, reducing the percentage of $\mathrm{LDH}$ release to $38.1 \pm 5.6 \%, 33.5 \pm 6.3 \%$, and $26.2 \pm 3.8 \%$ of the controls at $10 \mu \mathrm{M}, 25 \mu \mathrm{M}$ and $50 \mu \mathrm{M}$ propofol, respectively. Numbers of viable cells increased following propofol pretreatment, with $11.4 \pm 10.9 \%, 19.5 \pm 16.1 \%$, and $32.4 \pm 23.3 \%$ cell survival rates after pretreatment with $10 \mu \mathrm{M}, 25$ $\mu \mathrm{M}$ and $50 \mu \mathrm{M}$ propofol, respectively. Analyses of flow cytometry showed that the propofol pretreatment decreased the percentage of necrotic and late apoptotic cells.

Conclusions: Propofol protects HK-2 human kidney proximal tubular cells against $\mathrm{H}_{2} \mathrm{O}_{2}$-induced oxidative stress. (Korean J Anesthesiol 2012; 63: 441-446)

Key Words: $\mathrm{H}_{2} \mathrm{O}_{2}$, Oxidative stress, Propofol, Renal cell.

Received: August 7, 2012. Revised: 1st, August 29, 2012; 2nd, August 31, 2012. Accepted: September 3, 2012.

Corresponding author: Joung Uk Kim, M.D., Department of Anesthesiology and Pain Medicine, Asan Medical Center, 86, Asanbyeongwon-gil, Songpa-gu, Seoul 138-736, Korea. Tel: 82-2-3010-3860, Fax: 82-2-3010-6790, E-mail: jukim@amc.seoul.kr

(C) This is an open-access article distributed under the terms of the Creative Commons Attribution Non-Commercial License (http:// creativecommons.org/licenses/by-nc/3.0/), which permits unrestricted non-commercial use, distribution, and reproduction in any medium, provided the original work is properly cited. 


\section{Introduction}

Renal ischemia/reperfusion (I/R) damage can occur in many clinical situations such as during reno-vascular surgery, clamping of the aorta, shock, trauma, and renal transplantation. Acute tubular necrosis (ATN) and renal failure related to I/R are the main reasons for morbidity and mortality in hospitalized patients [1]. ATN arises as a result of damage created by free oxygen radicals that are formed during I/R [2]. Oxygen free radicals, such as superoxide anion, hydroxyl radicals and hydrogen peroxide $\left(\mathrm{H}_{2} \mathrm{O}_{2}\right)$ are key mediators of renal reperfusion injury [3]. These reactive oxygen species cause lipid peroxidation of the renal cell membrane, which results in intracellular calcium overload and subsequent necrotic cell death $[4,5]$.

Following renal transplantation, exposure of the graft to variable levels of $\mathrm{I} / \mathrm{R}$ damage delays graft function, and can even cause graft loss [6]. Hence, approaches that prevent I/R damage should promote graft functions and enhance graft lifetime. When any manipulation that involves a risk of renal ischemic damage is planned, it would be prudent to have prophylactic treatments or anesthetic techniques in place in order to avoid I/ R damage.

Propofol (2, 6-diisopropylphenol), a highly lipid-soluble anesthetic, is widely used for the induction and maintenance of general anesthesia. Propofol ameliorates I/R injury in several organs, including the heart [7], lungs [8], brain [9], liver [10], and testicles [11]. Some reports have described a protective effect of propofol against oxidative stress in rats at the nephrocyte [12] and whole-animal levels [13]. However, there have been few reports on the effects of propofol on oxidative stress in human kidney cells.

In this study, we used the HK-2 immortalized human proximal tubular cell line as a culture model, because proximal tubular cells are known to be the cell type most susceptible to ischemia in the kidney [14]. Moreover, HK-2 cells have been used to study renal physiology and pathophysiology in vitro [15]. We hypothesized that propofol would protect human kidney cells against oxidant-mediated damage. To test this hypothesis, we injured HK-2 cells with $\mathrm{H}_{2} \mathrm{O}_{2}$ and assessed cell death by measuring lactate dehydrogenase (LDH) release, counting viable cells, and performing flow cytometry on fluorescein isothiocyanate (FITC)-labeled Annexin V/propidium iodide (PI) double-stained cells.

\section{Materials and Methods}

\section{Culture of HK-2 human renal proximal tubular cells}

Immortalized human proximal tubular cells of the HK-2 cell line (American Type Culture Collection, Manassas, VA, USA) were grown and passaged in $25-\mathrm{cm}^{2}$ cell culture flasks containing culture medium (keratinocyte serum-free medium with $5 \mathrm{ng} / \mathrm{ml}$ epidermal growth factor and $40 \mathrm{mg} / \mathrm{ml}$ bovine pituitary extract; Gibco BRL, NY, USA) and antibiotics (100 $\mathrm{U} / \mathrm{ml}$ penicillin $\mathrm{G}, 100 \mu \mathrm{g} / \mathrm{ml}$ streptomycin and $0.25 \mu \mathrm{g} / \mathrm{ml}$ amphotericin B). Cultured cells were incubated at $37^{\circ} \mathrm{C}$ in a $100 \%$ humidified incubator containing $5 \% \mathrm{CO}_{2}$. Cells were plated in 24 -well plates at $80 \%$ confluence, and culture medium was replaced every 2 days. Three days after plating, HK-2 cells were challenged with $8 \mathrm{mM} \mathrm{H}_{2} \mathrm{O}_{2}$ (Sigma Chemical, St. Louis, MO, USA) diluted in serum-free medium containing different concentrations of propofol (Tocris Chemical Co, Ellisville, MO, USA) and incubated for 4 hours.

\section{Propofol and $\mathrm{H}_{2} \mathrm{O}_{2}$ treatment}

Depending on the groups, cells were incubated with $0 \mu \mathrm{M}$, $10 \mu \mathrm{M}, 25 \mu \mathrm{M}$, or $50 \mu \mathrm{M}$ propofol for 30 minutes and then incubated for a further 4 hours after the addition of $\mathrm{H}_{2} \mathrm{O}_{2}$ to a final concentration of $8 \mathrm{mM} \mathrm{H}_{2} \mathrm{O}_{2}$. Propofol was dissolved in dimethyl sulfoxide (DMSO; Sigma Chemical, St. Louis, MO, USA), yielding a final DMSO concentration in media of $0.0025-$ $0.0125 \%$. Tests showed that DMSO over this concentration range had no effect on oxidative stress or cell viability (data not shown).

\section{Measurement of cell death and cell viability}

Whereas LDH normally localized to the cytoplasm in HK-2 and most other cell types, its release in response to cell damage is a widely used indicator of incipient cell death. To quantify cell death, we measured LDH enzymatic activity in the collected medium using the spectrophotometric CytoTox $96{ }^{\circledR}$ NonRadioactive Cytotoxicity Assay (Promega, Madison, WI, USA), and then calculated the percentage of $\mathrm{LDH}$ release. The percentage of $\mathrm{LDH}$ release was calculated as $(\mathrm{LDH})_{\text {test }} /(\mathrm{LDH})_{\text {total }} \times 100$, where $(\mathrm{LDH})_{\text {test }}$ is the measured $\mathrm{LDH}$ level in the experimental medium and $(\mathrm{LDH})_{\text {total }}$ is the total cellular LDH level per well measured after killing all cells by addition of the lysis solution ( $1 \%$ Triton $\mathrm{X}-100)$ provided as part of the kit.

Cell viability was measured using the trypan blue dye exclusion method. After treatment protocols were performed, cells were harvested and stained with $0.4 \%$ trypan blue dye for 5 minutes. The number of viable cells and total cells were counted using a hemocytometer.

The number of remaining nonviable cells was expressed as a percentage of the total number of cells. 


\section{Annexin V-FITC/PI double-staining assay}

Cell death was further analyzed by double staining cells with FITC-labeled Annexin V and PI using the Annexin V-FITC apoptosis detection kit (BD Biosciences, San Jose, CA, USA). Both floating and adherent cells were collected and plated onto a 12 -well plate at $1 \times 10^{6}$ cells/well. Cells were washed with phosphate buffered saline (PBS) and collected by trypsinization. After centrifugation at $400 \times g$ for 5 minutes at $4^{\circ} \mathrm{C}$, pelleted cells were washed twice with cold PBS and then resuspended in Annexin V binding buffer. A total of $100 \mu$ of cell suspension was transferred to test tubes, to which $5 \mu$ l of FITC-labeled Annexin V and $5 \mu \mathrm{l}$ of PI were added. The cells were gently vortexed and incubated for 15 minutes at room temperature in the dark. After adding $200 \mu \mathrm{l}$ of binding buffer to each tube, the cells were analyzed by flow cytometry using the FACSCalibur system (BD Biosciences, San Jose, CA, USA). Annexin V-FITC and PI emissions were detected in the FL 1 and FL 2 channels using 525 and $575 \mathrm{~nm}$ emission filters respectively. The Annexin V-FITC-negative/PI-negative population was considered to include all normal healthy cells. Annexin V-FITC-positive/PInegative cells were regarded as a measure of early apoptosis. Annexin V-FITC-positive/PI-positive population was considered to represent late apoptotic or necrotic cells, and Annexin V-FITCnegative/PI-positive cells were considered to include necrotic cells [16]. The percentage distributions of normal, early apoptotic, late apoptotic, and necrotic cells were calculated using ModFitLT V3.0 software (BD Biosciences, San Jose, CA, USA).

\section{Statistical analysis}

Statistical analyses were performed using the SigmaStat

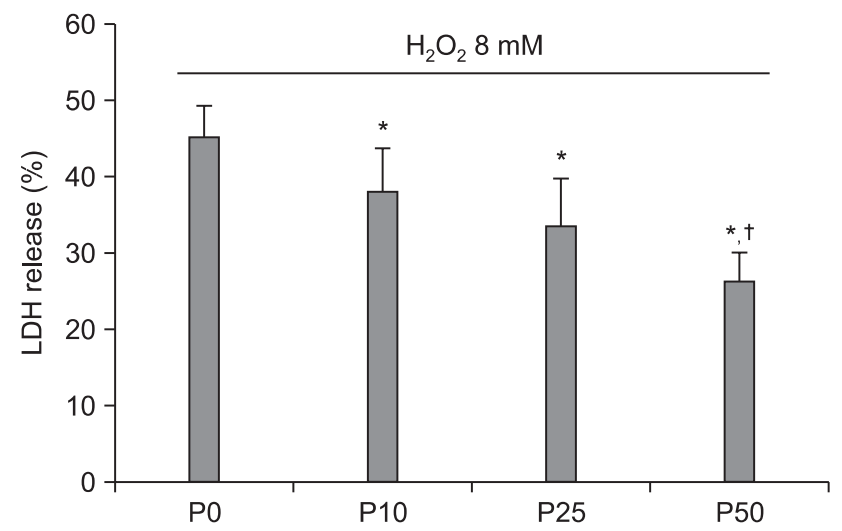

Fig. 1. Effects of propofol (P) pretreatment $(10 \mu \mathrm{M}, 25 \mu \mathrm{M}$ or 50 $\mu \mathrm{M})$ on lactate dehydrogenase (LDH) release from HK-2 cells after exposure to $8 \mathrm{mM} \mathrm{H}_{2} \mathrm{O}_{2}$ for 4 hours. Propofol decreased LDH release in a concentration-dependent manner. Values are shown as mean $\pm \mathrm{SD} .{ }^{*} \mathrm{P}<0.05$ compared with untreated cells. ${ }^{\dagger} \mathrm{P}<0.05$ compared with either $10 \mu \mathrm{M}$ or $25 \mu \mathrm{M}$ propofol pretreated cells. program (version 3.10; Systat software, Chicago, IL, USA). Multiple groups were compared using one-way analysis of variance (ANOVA) or Kruskal-Wallis one-way ANOVA on Ranks followed by pairwise multiple comparisons using a Tukey posthoc test as appropriate. In all comparisons, a P value less than 0.05 was considered to indicate a statistically significant difference. Data are presented as mean \pm SD unless stated otherwise.

\section{Results}

\section{Effect of propofol on LDH release}

Treatment of HK-2 cells for 4 hours by exposure to concentrations of $3 \mathrm{mM}, 5 \mathrm{mM}$, or $8 \mathrm{mM} \mathrm{H}_{2} \mathrm{O}_{2}$ or lysis solution (control group) increased the percentage of $\mathrm{LDH}$ release by $19.0 \pm 2.2 \%$, $22.4 \pm 8.8 \%, 41.2 \pm 6.5 \%$, and $100.0 \pm 7.4 \%$, respectively (data not shown). We chose to use $8 \mathrm{mM} \mathrm{H}_{2} \mathrm{O}_{2}$ in subsequent experiments as it induced an appropriate level of oxidative challenge. As shown in Fig. 1, propofol treatment significantly decreased the amount of $\mathrm{LDH}$ released at $8 \mathrm{mM} \mathrm{H}_{2} \mathrm{O}_{2}$. Compared with a rate of $\mathrm{LDH}$ release of $45.1 \pm 4.2 \%(\mathrm{n}=8)$ without propofol pretreatment, the rate of $\mathrm{LDH}$ release after pretreatment with $10 \mu \mathrm{M}$ propofol was $38.1 \pm 5.6 \%,(\mathrm{n}=8, \mathrm{P}<0.05)$, pretreatment with $25 \mu \mathrm{M}$ propofol caused $\mathrm{LDH}$ release at a rate of $33.5 \pm 6.3 \%$ ( $\mathrm{n}=8, \mathrm{P}<0.05$ ), and pretreatment with $50 \mu \mathrm{M}$ propofol caused $\mathrm{LDH}$ release at a rate of $26.2 \pm 3.8 \%(\mathrm{n}=8, \mathrm{P}<0.05)$.

The rate of $\mathrm{LDH}$ release after pretreatment with $50 \mu \mathrm{M}$ propofol was significantly different from that following pretreatment with either $10 \mu \mathrm{M}$ or $25 \mu \mathrm{M}$ of propofol $(\mathrm{P}<0.05)$ and there was no significant difference between rates of $\mathrm{LDH}$ release after pretreatment with $10 \mu \mathrm{M}$ propofol and pretreatment with $25 \mu \mathrm{M}$ propofol (Fig. 1).

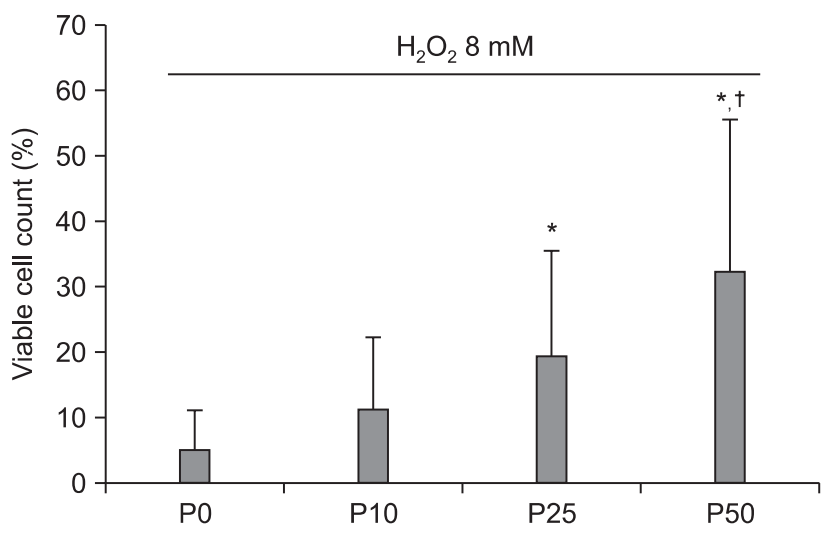

Fig. 2. Effects of propofol (P) pretreatment $(10 \mu \mathrm{M}, 25 \mu \mathrm{M}$ or $50 \mu \mathrm{M})$ on viable cell counts after exposure of HK-2 cells to $8 \mathrm{mM} \mathrm{H}_{2} \mathrm{O}_{2}$ for 4 hours. Propofol increased the percentage of trypan blue exclusion cells (viable cells) in a concentration-dependent manner. Values are shown as mean $\pm \mathrm{SD}$. $* \mathrm{P}<0.05$ compared with untreated cells. ${ }^{\dagger} \mathrm{P}<$ 0.05 compared with either $10 \mu \mathrm{M}$ or $25 \mu \mathrm{M}$ propofol pretreated cells. 


\section{Effect of propofol on viable cell counts}

After treatment of HK-2 cells with $8 \mathrm{mM} \mathrm{H}_{2} \mathrm{O}_{2}$ for 4 hours, 5.2 $\pm 6.0 \%(\mathrm{n}=20)$ of HK-2 cells were viable (control group). When HK-2 cells were treated with $25 \mu \mathrm{M}$ and $50 \mu \mathrm{M}$ propofol 30 minutes before exposure to $8 \mathrm{mM} \mathrm{H}_{2} \mathrm{O}_{2}$ and then incubated in the presence of $8 \mathrm{mM} \mathrm{H}_{2} \mathrm{O}_{2}$ for 4 hours, the percentages of viable cells significantly increased to $19.5 \pm 16.1 \%(n=20)$, and $32.4 \pm$ $23.3 \%(n=20)$, respectively $(P<0.05$ when compared with the control group, Fig. 2). The percentage increase in cell viability after pretreatment with $50 \mu \mathrm{M}$ propofol was significantly different from that after pretreatment with either $10 \mu \mathrm{M}$ or 25 $\mu \mathrm{M}$ propofol $(\mathrm{P}<0.05)$ and there was no significant difference in cell viability following pretreatment with either $10 \mu \mathrm{M}$ or 25 $\mu \mathrm{M}$ propofol (Fig. 2).

\section{Quantitation of $\mathrm{H}_{2} \mathrm{O}_{2}$-induced cell death with and without propofol pretreatment}

Annexin V-FITC binding analysis and PI staining were

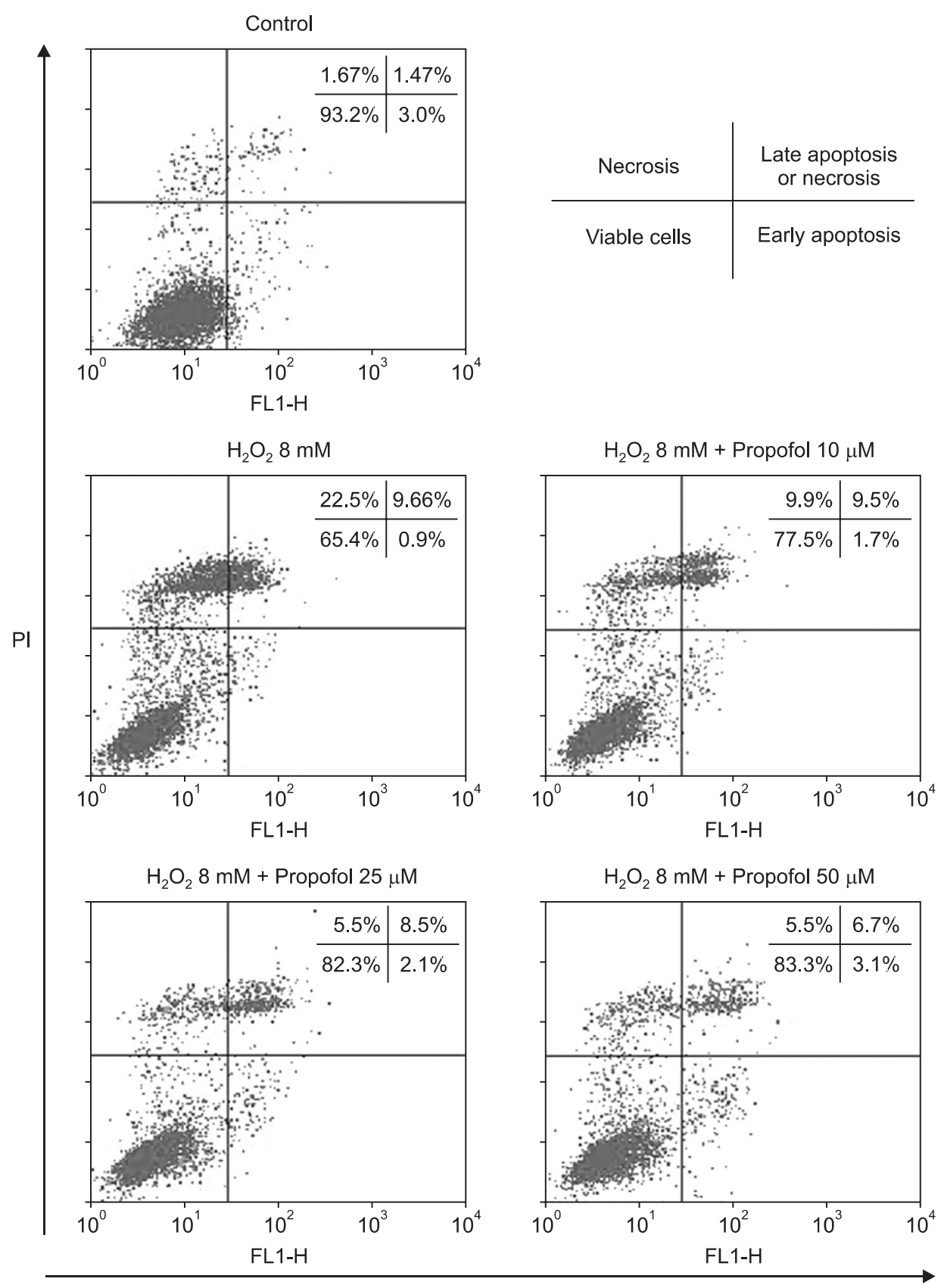

Annexin V-FITC
Fig. 3. Effects of propofol on $\mathrm{H}_{2} \mathrm{O}_{2}$ induced apoptosis and necrosis in HK-2 cells. Flow cytometric analysis of annexin V-FITC/PI double-stained cells. The cells were pretreated with propofol $(10 \mu \mathrm{M}, 25 \mu \mathrm{M}$ or $50 \mu \mathrm{M})$ for $30 \mathrm{~min}$ and then incubated with $8 \mathrm{mM} \mathrm{H}_{2} \mathrm{O}_{2}$ for 4 hours. The percentages of cells were calculated using the ModFitLT V3.0 software program (mean values are given; the experiment was performed five times). In each plot, the lower left quadrant represents viable cells, the upper left quadrant indicates necrotic cells, the lower right quadrant denotes early apoptotic cells, and the upper right quadrant represents necrotic or late apoptotic cells. FITC: fluorescein isothiocyanate, PI: propidium iodide. 
performed to quantify cell death arising from apoptosis and necrosis, respectively, with all of the experiments performed five times. Use of FACS to analyze, trypsinized cells revealed that the respective percentages of intact Annexin V-FITCnegative/PI-negative cells from the control and $\mathrm{H}_{2} \mathrm{O}_{2}$ group were $93.2 \pm 1.0 \%$ and $65.4 \pm 5.9 \%$ of the two populations. The numbers of intact cells were significantly increased ( $P$ $<0.05)$ in the propofol groups, with respective percentages after pretreatment with $10 \mu \mathrm{M}, 25 \mu \mathrm{M}$, and $50 \mu \mathrm{M}$ propofol of $77.5 \pm 1.4 \%, 82.3 \pm 2.0 \%$, and $83.3 \pm 2.7 \%$. As shown in Fig. 3 , pretreatment with propofol significantly decreased $(\mathrm{P}<$ 0.05) the number of Annexin V-FITC-negative/PI-positive cells. Respective percentages of these cells after pretreatment with 10 $\mu \mathrm{M}, 25 \mu \mathrm{M}$, and $50 \mu \mathrm{M}$ propofol were $9.9 \pm 0.6 \%, 5.5 \pm 0.8 \%$, and 5.5 $\pm 0.7 \%$ compared with cells treated with $\mathrm{H}_{2} \mathrm{O}_{2}$ alone $(22.5 \pm 3.7 \%)$. The numbers of annexin V-FITC-positive/PI-positive cells were significantly lower $(\mathrm{P}<0.05)$ in groups pretreatment with either $25 \mu \mathrm{M}$ or $50 \mu \mathrm{M}$ propofol (respective value of $8.5 \pm 0.4 \%$ and 6.7 $\pm 0.6 \%)$ compared to the $\mathrm{H}_{2} \mathrm{O}_{2}$ group $(9.7 \pm 0.6 \%)$. Dead cells were defined by the sum of the numbers of Annexin V-FITCnegative/PI-positive cells and annexin V-FITC-positive/PIpositive cells. As shown in Fig. 3, the percentages of dead cells were significantly lower $(\mathrm{P}<0.05)$ in cells from the propofol groups (respective values of $19.4 \pm 0.9 \%, 14.0 \pm 0.3 \%, 12.2 \pm 1.0 \%$ for cells pretreated with $10 \mu \mathrm{M}, 25 \mu \mathrm{M}$, and $50 \mu \mathrm{M}$ propofol) than in cells from the $\mathrm{H}_{2} \mathrm{O}_{2}$ group $(32.2 \pm 0.5 \%)$.

\section{Discussion}

In our present study, we evaluated whether propofol has a beneficial effect against renal I/R injury in human cells. The results indicated that propofol protects human proximal tubular cells against $\mathrm{H}_{2} \mathrm{O}_{2}$-induced oxidative stress in vitro. Dealing with the detrimental effects of renal I/R injury that can result in acute renal failure, remains a serious clinical challenge [17]. Oxygen free radicals are key mediators of renal reperfusion injury [3]. During the post-ischemic reperfusion period, reactive oxygen species, such as the superoxide anion, hydroxyls radical, and $\mathrm{H}_{2} \mathrm{O}_{2}$, are generated. These reactive oxygen species cause lipid peroxidation of the renal cell membrane, resulting in intracellular calcium overload and subsequent necrotic cell death $[4,5]$. In this study, we used $\mathrm{H}_{2} \mathrm{O}_{2}$-mediated oxidative injury of HK-2 cells as an in vitro model of reperfusion injury. We selected $\mathrm{H}_{2} \mathrm{O}_{2}$ as the source of oxidative stress in this experiment because it is a relatively stable oxidative stress radical that causes a variety of cell and tissue injuries. We used the HK-2 human renal proximal tubular cell culture model because renal cells are susceptible to $\mathrm{H}_{2} \mathrm{O}_{2}$-induced oxidative damage and renal cells with proximal tubular characteristics are much more susceptible to I/R injury than those with distal tubular characteristics [18]. Moreover, HK-2 cells are used to study in vitro renal physiology and pathophysiology [15]. In our preliminary $\mathrm{H}_{2} \mathrm{O}_{2}$ oxidative stress challenge tests using these cells, we found that a 4-hour exposure to $5 \mathrm{mM} \mathrm{H}_{2} \mathrm{O}_{2}$ resulted in an $\mathrm{LDH}$ release of $22.4 \pm 8.8 \%$, similar to the previously reported value of $25 \%$ after a 4-hour challenge with $5 \mathrm{mM} \mathrm{H}_{2} \mathrm{O}_{2}$ [19].

Many reports have demonstrated that some anesthetic agents can attenuate oxidative stress in the kidney. Sevoflurane has anti-inflammatory effects and anti-necrotic effects in $\mathrm{H}_{2} \mathrm{O}_{2}$-treated HK-2 cells [19]. Propofol, which is chemically similar to a phenol-based free radical scavenger [20], protects against oxidative stress in renal I/R injury [12]. Both of these studies involved measuring levels of serum creatinine and blood urea nitrogen and histological analysis of I/R injury in rat models of kidney damage. Histological findings from the two studies showed that propofol significantly reduced tissue necrosis. Another report, which suggested that propofol has antioxidant effects following kidney transplantation in humans, examined the impact of renal transplantation on oxidative stress and inflammation by measuring changes in the level of 8-iso- $\mathrm{PGF}_{2 \alpha}$ and 15-keto-dihydro-PGF ${ }_{2 \alpha}$, respectively [21]. The same study compared the antioxidant capacities of propofol and thiopentone during transplantation and after surgery. The levels of 8 -iso $\mathrm{PGF}_{2 \alpha}$ were significantly lower in the propofol group than in the thiopentone group [21]. However, propofol and thiopentone were used as induction agents in these experiments, not as maintenance agents. The plasma concentrations of propofol are reportedly 40$60 \mathrm{mM}$ at the time of induction of anesthesia, and 10-25 mM during the maintenance of anesthesia [22]. To date, reports on the protective effects of propofol at the maintenance dose and studies on human renal cells are rare. Therefore we chose propofol concentrations of 10-50 mM, spanning the maintenance-dose range, to determine the clinical relevance of the protective effects of propofol. Pretreatment with $50 \mathrm{mM}$ propofol in a sample group was significantly different from $10 \mu \mathrm{M}$ or $25 \mu \mathrm{M}$ of propofol in another sample group in the experiments measuring LDH release and viable cell count, but not in flow cytometric analysis. There were many other causes for that difference, one of which was that more figures from future data might be needed for accurate flow cytometric study.

It is possible that the concentration of propofol that produces antioxidant effects may differ in a tissue and species-specific manner. Some authors have reported no beneficial effect of propofol in cardiac surgical patients when administrated at a conventional clinical concentration of $2-4 \mathrm{mg} / \mathrm{ml}(11-23$ $\mathrm{mM}$ ) compared with the volatile anesthetic sevoflurane [23]. In contrast, propofol, when given at $6-8 \mathrm{mg} / \mathrm{ml}$ (35-46 mM) during myocardial ischemia and the early phase of reperfusion, attenuates free-radical-mediated and inflammatory com- 
ponents of myocardial reperfusion injury in patients undergoing elective coronary artery bypass graft surgery more effectively than the volatile anesthetic isoflurane [24]. These observations suggest that the potential cardioprotective effects of propofol in patients are dose-dependent. Divergent effects of propofol have also been reported with respect to vascular endothelial cells [25].

In conclusion, propofol attenuates renal oxidative injury in vitro, which has potential clinical implications. Thus, propofol may be a good anesthetic agent in surgeries that carry a risk of renal I/R injury, such as kidney transplantation. However, further in vivo and in vitro studies are needed to elucidate the protective mechanism involved and to establish the optimally protective concentration range of propofol in humans.

\section{Acknowledgements}

This study was supported by a grant (2005-177) from the Asan Institute for Life Sciences, Seoul, Korea.

\section{References}

1. Lieberthal W, Nigam SK. Acute renal failure. I. Relative importance of proximal vs. distal tubular injury. Am J Physiol 1998; 275: F62331.

2. Paller MS, Hoidal JR, Ferris TF. Oxygen free radicals in ischemic acute renal failure in the rat. J Clin Invest 1984; 74: 1156-64.

3. Paller MS, Neumann TV. Reactive oxygen species and rat renal epithelial cells during hypoxia and reoxygenation. Kidney Int 1991; 40: 1041-9.

4. Salahudeen AK. Role of lipid peroxidation in $\mathrm{H}_{2} \mathrm{O}_{2}$-induced renal epithelial (LLC-PK1) cell injury. Am J Physiol 1995; 268: F30-8.

5. Sheridan AM, Fitzpatrick S, Wang C, Wheeler DC, Lieberthal W. Lipid peroxidation contributes to hydrogen peroxide induced cytotoxicity in renal epithelial cells. Kidney Int 1996; 49: 88-93.

6. Peeters P, Vanholder R. Therapeutic interventions favorably influencing delayed and slow graft function in kidney transplantation: mission impossible? Transplantation 2008; 85(7 Suppl): S317.

7. Lim KH, Halestrap AP, Angelini GD, Suleiman MS. Propofol is cardioprotective in a clinically relevant model of normothermic blood cardioplegic arrest and cardiopulmonary bypass. Exp Biol Med (Maywood) 2005; 230: 413-20.

8. Balyasnikova IV, Visintine DJ, Gunnerson HB, Paisansathan C, Baughman VL, Minshall RD, et al. Propofol attenuates lung endothelial injury induced by ischemia-reperfusion and oxidative stress. Anesth Analg 2005; 100: 929-36.

9. Ergun R, Akdemir G, Sen S, Tasci A, Ergungor F. Neuroprotective effects of propofol following global cerebral ischemia in rats. Neurosurg Rev 2002; 25: 95-8.

10. Wang H, Xue Z, Wang Q, Feng X, Shen Z. Propofol protects hepatic L02 cells from hydrogen peroxide-induced apoptosis via activation of extracellular signal-regulated kinases pathway. Anesth Analg 2008; 107: 534-40.

11. Unsal A, Devrim E, Guven C, Eroglu M, Durak I, Bozoklu A, et al. Propofol attenuates reperfusion injury after testicular torsion and detorsion. World J Urol 2004; 22: 461-5.

12. Wang HH, Zhou HY, Chen CC, Zhang XL, Cheng G. Propofol attenuation of renal ischemia/reperfusion injury involves heme oxygenase-1. Acta Pharmacol Sin 2007; 28: 1175-80.

13. Yuzbasioglu MF, Aykas A, Kurutas EB, Sahinkanat T. Protective effects of propofol against ischemia/reperfusion injury in rat kidneys. Ren Fail 2010; 32: 578-83.

14. Ryan MJ, Johnson G, Kirk J, Fuerstenberg SM, Zager RA, Torok-Storb B. HK-2: an immortalized proximal tubule epithelial cell line from normal adult human kidney. Kidney Int 1994; 45: 48-57.

15. Racusen LC, Monteil C, Sgrignoli A, Lucskay M, Marouillat S, Rhim JG, et al. Cell lines with extended in vitro growth potential from human renal proximal tubule: characterization, response to inducers, and comparison with established cell lines. J Lab Clin Med 1997; 129: 318-29.

16. Vermes I, Haanen C, Steffens-Nakken H, Reutelingsperger C. A novel assay for apoptosis. Flow cytometric detection of phosphatidylserine expression on early apoptotic cells using fluorescein labelled Annexin V. J Immunol Methods 1995; 184: 39-51.

17. Aronson S, Blumenthal R. Perioperative renal dysfunction and cardiovascular anesthesia: concerns and controversies. J Cardiothorac Vasc Anesth 1998; 12: 567-86.

18. Weinberg JM, Buchanan DN, Davis JA, Abarzua M. Metabolic aspects of protection by glycine against hypoxic injury to isolated proximal tubules. J Am Soc Nephrol 1991; 1: 949-58.

19. Lee HT, Kim M, Jan M, Emala CW. Anti-inflammatory and antinecrotic effects of the volatile anesthetic sevoflurane in kidney proximal tubule cells. Am J Physiol Renal Physiol 2006; 291: F67-78.

20. Green TR, Bennet SR, Nelson VM. Specificity and properties of propofol as an antioxidant free radical scavenger. Toxicol Appl Pharmacol 1994; 129: 163-9.

21. Basu S, Meisert I, Eggensperger E, Krieger E, Krenn CG. Time course and attenuation of ischaemia-reperfusion induced oxidative injury by propofol in human renal transplantation. Redox Rep 2007; 12: 195-202.

22. Fan SZ, Yu HY, Chen YL, Liu CC. Propofol concentration monitoring in plasma or whole blood by gas chromatography and highperformance liquid chromatography. Anesth Analg 1995; 81: 175-8.

23. Bein B, Renner J, Caliebe D, Scholz J, Paris A, Fraund S, et al. Sevoflurane but not propofol preserves myocardial function during minimally invasive direct coronary artery bypass surgery. Anesth Analg 2005; 100: 610-6.

24. Corcoran TB, Engel A, Sakamoto H, O'Callaghan-Enright S, O'Donnell A, Heffron JA, et al. The effects of propofol on lipid peroxidation and inflammatory response in elective coronary artery bypass grafting. J Cardiothorac Vasc Anesth 2004; 18: 592-604.

25. Luo T, Xia Z. A small dose of hydrogen peroxide enhances tumor necrosis factor-alpha toxicity in inducing human vascular endothelial cell apoptosis: reversal with propofol. Anesth Analg 2006; 103: 110-6. 